\title{
MENUMBUHKAN KECERDASAN EMOSIONAL PADA ANAK USIA DINI MELALUI KESENIAN
}

\author{
Chofifah Nurul Hidayah \\ Fakultas Keguruan dan Ilmu Pendidikan Universitas Sebelas Maret Surakarta \\ Email: cnuru199@gmail.com
}

Hidayah, Chofifah Nurul. (2020). Menumbuhkan Kecerdasan Emosional Pada Anak Usia Dini Melalui

Kesenian. Jurnal Pelita PAUD, 4(2), 269-275.

doi: https://doi.org/10.33222/pelitapaud.v4i1.987

\begin{abstract}
Abstrak: Penulisan jurnal ini bertujuan untuk mengetahui bagaimana cara menumbuhkan kecerdasan emosional pada anak usia dini, dan untuk menumbuhkan kecerdasan emosional pada anak itu memerlukan peran besar orangtua serta untuk menumbuhkannya dapat melalui berbagai hal salah satu nya melalui kesenian. Jenis penelitian ini merupakan penelitian kualitatif atau studi literatur dengan subjek penelitian anak usia 4-6 tahun. Teknik pengumpulan data yaitu dengan mengumpulkan data dari beberapa sumber yang tertera dalam jurnal referensi. Hasil penelitian menunjukkan bahwa dalam kesenian seperti metode bercerita atau mendongeng, melalui musik feeling, melalui bermain serta tak luput dari peran serta orangtua ketika memberikan pendidikan terhadap anaknya sehingga dapat memunculkan kecerdasan emosional seperti yang diharapkan

Kata kunci: anak usia dini, kecerdasan emosional, kesenian

Abstract: Writing this journal aims to find out how to grow emotional intelligence in early childhood, and to grow emotional intelligence in children requires a great role of parents and to grow it through various things one of them through art. This type of research is a qualitative study or study of literature with research subjects children aged 4-6 years. Data collection techniques is to collect data from several sources listed in reference journals. The results showed that in arts such as the method of storytelling or storytelling, through feeling music, through playing and not escape from the participation of parents when providing education to their children so that it can bring emotional intelligence as expected.
\end{abstract}

http://jurnal.upmk.ac.id/index.php/pelitapaud. 


\section{PENDAHULUAN}

Pendidikan Anak Usia Dini (PAUD) hakikatnya merupakan pendidikan yang diselenggarakan dengan tujuan untuk memfasilitasi pertumbuhan dan perkembangan anak secara menyeluruh atau terpenuhinya segala aspek perkembangan anak. Beberapa aspek yang perlu di kembangkan yaitu diantaranya aspek Nilai Agama Moral (NAM), aspek fisik motorik, aspek kognitif, aspek sosial emosional, aspek bahasa , dan aspek seni. Maka salah satu dari beberapa aspek tersebut aspek yaitu sosial emosional yang mempunyai peran sebagai penjalin hubungan yang baik antar sesama. Proses sosial emosional disini juga sangat diperlukan dalam belajar baik belajar dalam satu tim, maupun belajar dalam kelompok, karena dengan begitu anak akan berhubungan dengan teman sehingga ia harus bisa dalam mengontrol emosi nya.

Banyak dari penelitian mengenai kecerdasan emosional pada anak usia dini masih dalam angka yang rendah, artinya dalam pengembangan sosial emosional pada anak usia dini mengalami penghambatan yang mana hal tersebut bisa saja membawa dampak buruk hingga ia tumbuh besar nanti. Walaupun sebenarnya menjadi hal wajar ketika masa kanak-kanak masih memiliki sikap ego yang sangat tinggi, tetapi hal tersebut perlu diajarkan sejak dini pula agar sikap ego yang tinggi tersebut tidak dibawa sampai ia tumbuh besar nanti, dan ia dapat berperilaku yang baik terhadap oranglain.

Untuk itu terdapat sebuah pendapat oleh Gardner (Mulyasa, 2012) mengatakan bahwa

"Anak usia dini mempunyai intelegensi atau kecerdasan yang perlu dikembangkan secara optimal" hal tersebut ditambah dan dilanjutkan (Mulyasa, 2012) bahwa “" kecerdasan anak yang perlu dikembangkan di antaranya kecerdasan interpersonal adalah kecerdasan untuk memahami hal-hal yang terjadi pada dirinya. Kecerdasan ini ditandai dengan kemampuan anak untuk mengungkapkan perasaan atau isi hati, sedangkan kecerdasan intrapersonal yang merupakan kecerdasan seseorang untuk menjalin hibungan dengan orang lain." Kecerdasan manusia menurut pendapat lain dikemukakan oleh Howard Gardner (2003) bahwa kecerdasan manusia dibagi menjadi delapan enis diantaranya 1) Intellegence Quotient (IQ) atau kecerdasan intelektual, yaitu kemampuan potensional seseorang untuk memelajari sesuatu menggunakan alatalat berpikir, biasanya kecerdasan ini diukur dari sisi kekuatan verbal dan logika seseorang, 2) Emotional Quotient (EQ) atau kecerdasan emosional, kecerdasan ini mempunyai lima komponen pokok yakni kesadaran diri, manajemen emosi, motivasi, empati dan mengatur sebuah hubungan sosial. Disebutkan dalam buku Emotional Intellegence oleh Daniel Goleman yaitu kontribusi IQ bagi keberhasilan seseorang hanya sekitar $20 \%$, dan sisanya $80 \%$ ditentukan oleh kecerdasan emosional, 3) Spiritual Quotient (SQ) yaitu spiritual kecerdasan yang mengangkat fungsi jiwa sebagai perangkat internal diri yang memiliki kemampuan dan kepekaan dalam melihat makna yang ada dibalik sebuah kenyataan atau kejadian tertentu. Sehingga dapat diketahui bahwa kecerdasan sosial merupakan kemampuan sosial yang meliputi kemampuan untuk mengendalikan diri, memiliki daya tahan ketika menghadapi suatu masalah, mampu mengendalikan impuls, memotivasi diri, mampu mengatur suasana hati, kemampuan berempat, dan membina hubungan dengan oranglain.

Dari tiga poin tentang kecerdasan manusia diatas Emotional Quotient (EQ) menempati kedudukan yang memiki peran paling besar dalam keberhasilan hidup seseorang, maka dari itu sangat diperlukan bagi orangtua maupun pendidik untuk dapat mengembangkan kemampuan tersebut secara tepat,selain dari pola pengasuhan orangtua yang diperhatikan ternyata mengembangkan kemampuan atau kecerdasan emosional anak dapat melalui permainan karena disebutkan bahwa kecerdasan emosional dapat tumbuh melalui bermain, karena dalam bermain anak melakukan interaksi sosial bersama oranglain, melalui bidang kesenian seperti bercerita, mendengarkan atau bermain musik, gerak dan lagu dan lain-lain, kesenian merupakan keseluruhan sistem yang melibatkan proses penggunaan imajinasi manusia secara kreatif di dalam sebuah kelompok masyarakat dengan kebudayaan tertentu (William A. Haviland), hal ini dikarenakan dalam 
Vol. 4 No. 2 Juni 2020

bercerita, mendengarkan musik dan kegiatan seperti kesenian lainnya mengandung aspek hiburan yang menyenangkan dan dapat menjadi metode belajar yang tidak menggurui dan fleksibel, dimana anak akan menjumpai suasana menggembirakan sebagai suasana bermain tidak belajar karena pada anak usia dini memiliki konsep bermain sambil belajar. Jenis kesenian yang dapat pula digunakan dalam pertumbuhan kecerdasan emosional anak yaitu kesenian tari seperti yang dikatakan oleh John Martin dalam Soedarsono (1978:1) bahwa substansi baku tari adalah gerak dan ritme. gerak atau aktifitas motorik dalam tari juga terdapat pada ekspresi dari segala pengalaman emosional.

Penulisan artikel ini memiliki tujuan untuk menumbuhkan kesadaran bagi orangtua maupun pendidik bahwa kecerdasan emosional perlu sekali untuk diperhatikan, karena masih banyak orangtua yang kurang paham akan pola asuh yang tepat bagi perkembangan anaknya khususnya pada bidang aspek sosial emosional, dan keterlibatan atau peran orangtua juga sangat penting dalam memberikan bimbingan dan asuhan kepada anak yang mana hal tersebut akan berpengaruh pada tahap perkembangan selanjutnya Jika dalam penelitian lain hanya befokus pada satu cara saja maka dalam artikel ini menggabungkan berbagai cara yang dapat membantu menumbuhkan kecerdasan emosional pada anak usia dini melalui bidang kesenian seperti halnya bermain musik, gerak dan lagu ,bercerita atau mendongeng, serta melaui permainan tradisional dimana dalam hal tersebut melibatkan anak untuk berinteraksi dengan teman sebayanya serta tak lupa pola asuh yang digunakan orangtua untuk mendidik anaknya supaya dapat berperilaku yang baik terhadap sesame baik dengan teman sebaya maupun dengan orang yang lebih tua sesuai nilai dan norma serta sesuai dengan kehidupan masyarakat.

\section{METODE PENELITIAN}

Penelitian ini menggunakan penelitian kualitatif yaitu penelitian yang dapat menghasilkan informasi berupa data deskribtif danhasil tersebut merupakan kumpulan dari beberapa sumber yang digunakan sebagai bahan penelitian, dan menggunakan pendekatan studi pustaka

\section{Jenis Penelitian dan Subjek Penelitian}

Menggunakan pendekatan studi pustaka yaitu dengan cara peneliti memeriksa bahan-bahan yang telah ditulis oleh orang lain atau menggunakan sumber-sumber referensi seperti jurnal ilmiah, buku referensi, literatur, ensiklopedia, karangan ilmiah, dan lain-lain, kegiatan dalam penelitian ini ialah dengan membaca atau menelaah seluruh dokumen yang telah diterbitkan sebagai teknik pengumpulan data nya. Serta subjek penelitiannya adalah anak usia dini berusia 46 tahun (anak TK)

\section{HASIL PENELITIAN DAN PEMBAHASAN}

Berdasarkan hasil penelitian dalam kegiatan studi literatur yang dilakukan diperoleh sebuah data bahwa dalam mendidik anak usia dini untuk meningkatkan kecerdasan emosional sangat diperlukan sekali peran dari kedua orangtua untuk membentuk karakter prososial pada anak sehingga akan tercipta kecerdasan emosional. Seperti halnya yang dapat dilakukan untuk membantu menumbuhkan kecerdasan emosional pada anak usia dini yaitu melalui bidang kesenian. Diketahui dalam sebuah penelian tertuliskan bahwa kecerdasan emosional anak dapat ditingkatkan melalui kegiatan bermain musik atau kegiatan gerak dan lagu. Menurut Newcomb dalam Ali Nugraha (2007:818) (Priyanti \& Setyowati, 2017) permainan musik atau feeling band merupakan sebuah permainan yang dilakukan dengan cara membunyikan instrumen musik sesuai dengan ekspresi perasaan. Dalam hal ini alat musik yang dapat digunakan untuk melatih kecerdasan emosional paada anak yaitu alat musik perkusi (alat musik yang dipukul) karena anak dapat mengekspresikannya emosinya dengan cara memukul alat musik tersebut sesuai perasaannya. Melalui permainan musik ini anak akan lebih tertarik untuk melakukan proses pembelajaran. Permainan musik ini selain dapat untuk mengembangkan kecerdasan emosional pada anak juga dapat digunakan sebagai alat terapi pada anak yang berkebutuhan khusus biasanya pada anak yang memiliki gangguan pada emosionalnya.

Selain itu musik memiliki manfaat bagi anak antara lain: a) mengoptimalkan perkembangan 
otak, b) meningkatkan multiple intelligence, c) memfasilitasi emotional bonding (ikatan emosional) orangtua dan anak, d)membangun keterampilan sosial dan emosional anak, e) meningkatkan perhatian terhadap tugas-tugas dan kemampuan bicara, f) mengembangkan kontrol impulsif dan perkembangan motorik, dan g) menjembatani kreativitas dan kesenangan

Menumbuhkan kecerdasan emosional juga dapat dilakukan melalui kemampuan gerak tari. Menurut Denisson dalam Lily Djokosetio Sidiarto menjelaskan bahwa faktor esensial yang mempengaruhi perkembangan otak adalah faktor internal seperti genetik atau keturnan, dan faktor ksternal berupa gizi seimbang, interaksi, seni dan gerakan (Sidiarto, 2007:142). Dengan begitu melalui gerak tari untuk anak usia dini dapat membantu mengembangkan perkembangan fisik dan pola gerak, jika latihan gerak tari tersebut dilakukan bersama dengan temannya, maka diharapkan dapat membantu mengembangkan kemampuan dasar bersosialisasi, mengatur emosinya, serta meningkatkan daya berpikir. Dalam hal ini sama dengan model pembelajaran kooperatif yaitu memberikan kesempatan pada anak untuk bekerja secara berkelompok, sehingga dapat memberikan pengalaman pada anak untuk berinteraksi dengan temannya dan hal ini dapat mempengaruhi kecerdasan emosional pada anak.

Tari (Yetti, 2012) merupakan salah satu bagian dari kesenian. Salah satu dari bagian seni tari yaitu keindahan gerak anggotaanggota badan manusia yang bergerak, berirama, dan berjiwa yang harmonis (Bagong Kussudiar-djo, 1981:16) yang memiliki arti bahwa sei tari merupakan gerak yang dilakukan oleh manusi sebagai ekspersi dari jiwa manusia yang memiliki unsur keindahan, berirama, beriwa, dan harmonis, selain itu dengan melakukan gerakan tari juga dapat melatih untuk mengembangkan kepekaan rasa gerak dan irama. Kepekaan rasa atau ungkapan rasa dalam tari berkaitan dengan emosi seseorang, sehingga jika anak usia dini berlatih sebuah gerakan dalam tari berarti ia telah memiliki pengalaman dalam berlatih mengendalikan emosi yang mana hal ini berkaitan dengan kecerdasan emosional.
Cara lain yang dapat digunakan untuk menumbuhkan kecerdasan emosional pada anak usia dini yaitu dengan metode bercerita. Metode bercerita (Hariyanto, 2018) merupakan salah satu kegiatan yang digunakan dalam pembelajaran anak usia dini yaitu dengan membacakan sebuah cerita, baik secara lisan atau bacaan (reading story). Metode ini sangat efektif jika diterapkan pada anak usia dini, karena hal ini dapat diguankan sebagai penyampaian berbagai pesan edukasi dalam cerita yang mampu merangsang kecerdasan emosionalnya sejak dini.

Bercerita juga salah satu metode yang digunakan untuk pembelajaran pada anak usia dini yang bertujuan untuk menghindari kejenuhan ketika sedang belajar atau belajar terasa menyenangkan. Selain itu terdapat pula manfaat ketika membacakan dongeng atau cerita pada anak usia dini yaitu ikatan emosional yang terbangun antara orangtua dan anak dapat memperkuat kecerdasan emosionalnya, karena dari cerita yang dibacakan dapat menstimulasi daya imajinasi anak dan dapat memupuk kreativitas serta dengan bercerita dapat membangun kepribadian anak yang baik, karena ketika dengan cerita sangat menggugah emosi anak terlibat didalamnya dan melalui cerita itulah perilaku seorang anak dapat dipengaruhi dan mengajak anak untuk mengambil keputusan dari sebuah permasalahan yang muncul dalam cerita secara sederhana. Dikatakan oleh para ahli bahwa jika membacakan cerita pada anak mulai dari lahir sampai usia 5 tahun selama 15 menit saja sama halnya dengan memberikan jutaan kalori gizi bagi otak ketika sedang tumbuh dan berkembang seperti ini.

Kegiatan kesenian lain yang dapat menumbuhkan kecerdasan emosional yaitu melalui permainan tradisonal. Terdapat sebuah pendapat yang dikatakan oleh Iswinarti (2010) dan Wardani (2010) (Gandana, 2016) yaitu tentang ide yang terkait dengan tindakan yang dapat dijadikan jalan untuk menempuh kematangan kecerdasan emosional pada anak usia dini yaitu melalui penerapan permainan tradisional "kaulinan barudak" , permainan tradisional " kaulinan barudak " merupakan warisan yang berupa permainan untuk anak-anak yang dilakukan secara manual dan dekat dengan alam. Selain itu terdapat makna yang memberikan stimulus 
untuk mengembangkan setiap potensi dan kecerdasan yang dimiliki setiap anak ketika melakukan permainan tersebut (Iswinarti, 2010; dan Wardani, 2010). Manfaat yang diperoleh dari permainan tradisional antara lain: 1) anak menjadi lebih kreatif karena permainan tradisional biasanya dibuat langsung oleh pemainnya, 2) permainan dapat digunakan sebagai terapi untuk anak yaitu dengan berteriak, tertawa, dan bergerak anak dapat melepaskan emosinya secara bebas, 3) mengembangkan kecerdasan intelektual, 4) mengembangkan kecerdasan emosional, 5) mengembangkan kecerdasan logika, 6) mengembangkan kecerdasan spasial, 7) mengembangkan kecerdasan natural, 8) mengembangkan kecerdasan kinestetik, 9) mengenal konsep ruang dan berganti peran (teatrikal), 10) mengembangkan kecerdasan musikal, serta 11) mengembangkan kecerdasan spiritual (Yetti, 2012)(Ramadhan Lubis, 2018).

Dalam jurnal disebutkan yang termasuk permainan tradisional "kaulinan barudak" yang berasal dari Tasikmalaya antara lain seperti sondah, congkak, lompat tali, balap kelareng sendok, memasukkan paku/pensil dalam botol, sendal batok serta dam-daman. Dalam jurnal penelitian dilakukan dan mengambil beberapa poin kemampuan yang dapat di teliti untuk meningkatkan kecerdasan emosional pada anak melalui permainan tradisional "kaulinan barudak" seperti kemampuan menyadari diri sendiri, kemampuan mengelola emosi sendiri, kemampuan memotovasi diri senidiri, kemampuan bersikap empati, dan kemampuan menjalin hubungan sosial dan dari semua poin yang digunakan tersebut merupakan bagian dari pengertian kecerdasan emosional. Hasil yang diperoleh dalam penelitian tersbut yaitu melalui permainan tradisional yang diterapkan dapat membantu menumbuhkan atau meningkatkan kecerdasan emosional pada anak secara optimal.

Selanjutnya dari beberapa kegiatan kesenian diatas yang dapat digunakan sebagai peningkatan kecerdasan emosional pada anak, juga perlunya peran penting dari orang tua untuk ikut serta dalam mendidik anak untuk mengembangkan potensi sosial pada anak bidang kecerdsan emosional. Orangtua dan anak terdapat dalam satu ikatan yang berbentuk sebagai hubungan emosional yang tercermin dalam perilaku, ikatan emosional tersebut memberikan pencitraan terhadap institusi keluarga dimana orangtua berperan sebagai pendidik dalam keluarga sehingga sangat diperlukan dalam keluarga tersebut menjadi keluarga yang positif dan memeperhatikan pola asuh yang tepat ketika memberikan pendidikan kepada anak. Pola asuh yang tepat untuk perkembangan anak menurut Baumrind dan Hert dkk yaitu pola asuh otoritatif karena orangtua otoritatif memberi keseimbangan antara pembatasan dan kebebasan, artinya di satu sisi memberi kesempatan pada anak dalam mengeeksplor segala sesuatu terlebih untuk mengembangkan kepercayaan diri anak, namun juga membatasi anak untuk melakukan sesuatu dengan batas standar, karena dalam pola asuh ini orangtua melibatkan anak dalam kegiatan memberi dan menerima secara verbal dan emperbolehkan anak mengutarakan pandangan mereka, sehingga anak dapat mengarahkan diri, bertanggung jawab, memiliki rasa ingin tahu, dan memiliki ketenangan diri yang mana hal ini merupakan pencerminan dari keluarga yang positif.

Untuk itu (Haryati \& Atmaja, n.d.) pertumbuhan anak yang baik umumnya disertai dengan perkembangan kepekaan yang mana sangat dibutuhkan terutama pada saat seseorang anak memulai pergaulan dalam lingkungan sosial yang makin luas (NA.I \& P.B, 2011:50). Oleh karena itu perlunya memberikan pendidikan kepada anak sedini mungkin tentang nilai-nilai dan pesan moral. Kecerdasan emosional pada anak akan terbentuk dan berkembang ketika masa sekolah, hal ini dikarenakan anak sudah mulai bersosialisasi dengan banyak orang, maka dari itu selain peran orangtua sebagai pendidik di dalam keluarga juga perlunya peran dari guru untuk dapat mengontrol perkembangan anak ketika di sekolah terutama tentang mengontrol emosi anak. Terdapat penelitian yang dilakukan untuk mengetahui bentuk kecerdasan emosional pada anak dan hasilnya belum sesuai harapan, hal tersebut disebabkan kurangnya kedisiplinan, kemandirian, pemarah, dan pembangkang. Maka dari itu peran orangtua sangat dibutuhkan untuk dapat membentuk karakter yang baik pada anak sesuai nilai dan norma yang berlaku. Ternyata 
P ISSN 2548-6284 E ISSN 2615-0360

Vol. 4 No. 2 Juni 2020

kecerdasan emosional pada anak usia dini dapat pula berperan dalam pendidikan karakter. Pendidikan karakter menurut Licklona (1991) bahwa pendidikan karakter merupakan upaya yang sungguh-sungguh untuk membantu seseorang memahami, peduli dan bertindak dengan landasan nilai-nilai etis. sehingga jika berhasil dalam menumbuhkan kecerdasan emosional pada anak usia dini maka ia akan berkarakter sesuai dengan nilainilai dan norma yang berlaku, dan tidak akan menyimpang jika berperilaku karena sudah mempunyai pegangan dalam dirinya bagaimana ia berperilaku terhadap orang lain melalui kecerdasan emosionalnya.

\section{SIMPULAN}

Dari beberapa uaraian diatas dapat disimpulkan bahwa sangatlah diperlukan kecerdasan emosional itu ada pada anak usia dini, karena dengan adanya kecerdasan emosional pada anak akan membentuk karakter yang baik sesuai dengan nilai dan norma yang berlaku. Untuk membentuk atau meningkatkan kecerdasan emosional pada anak dapat dilakukan melalui beberapa kegiatab kesenian seperti , bermain musik, melakukan gerakan tari, model bercerita atau mendongeng kepada anak serta melalui kegiatan permainan tradisional yang mana beberapa kegiatan tersebut haruslah dilakukan dan disesuaikan ketika menerapkannya kepada anak usia dini yaitu dengan mengutamakan karakteristik anak bermain sambil belajar. Jika memberikan pengajaran kepada anak usia dini buatlah suasana sperti tidak sedang belajar yaitu suasana yang menyenangkan hal ini bertujuan untuk menghilangkan kejenuhan pada anak usia dini sehingga apa yang disampaikan dan yang ia dapat dalam kegiatan tersebut membekas untuk kehidupan selanjutnya. Selain itu tidak kalah penting peran serta pendidik dan orangtua dalam membantu mengembangkan dan meningkatkan kecerdasan emosional pada anak usia dini melalui pendidikan yang diberikan serta pola asuh yang tepat terhadap anak usia dini.

\section{DAFTAR PUSTAKA}

Anita Fitriya. (2019). optimalisasi perkembangan kecerdasan emosional. Journal of Chemical Information and Modeling, 53(9), 1-15. https://doi.org/10.1017/CBO9781107415324
.004

Fitriyani, L. (2015). Peran pola asuh orang tua dalam mengembangkan kecerdasan emosi anak. Lentera, XVIII(1), 93-110.

Gandana, G. (2016). Meningkatkan Kecerdasan Emosional Anak Usia Dini Melalui Permainan Tradisional "Kaulinan Barudak" Di Taman Kanak-Kanak. Pedagogik Pendidikan Dasar, 4(1), 58-72.

Hariyanto. (2018). Menanamkan kecerdasan emosional pada anak usia dini melalui cerita dan musik. 2(2).

Haryati, S. Y., \& Atmaja, J. R. (n.d.). PENGARUH PENGAWASAN (CONTROLLING ) ORANG TUA PENDAHULUAN Peran orang tua dan pendidik pada dasarnya mengarahkan anak- anak sebagai generasi unggul, karena potensi anak tidak akan tumbuh dengan sendirinya tanpa bantuan orang Mereka subur untuk memerlukan. 91103.

Kusniapuantari, D., \& Suryono, Y. (2014). Pengaruh Kerja Sama Antara Pendidik Dan Orangtua Terhadap Pengembangan Kecerdasan Emosional Anak the Effect of the Cooperation Between Teachers and Parents on the Development of the Emotional Intelligence of the Children. Jurnal Pendidikan Dan Pemberdayaan Masyarakat, 1(1), 18-31.

Perbowosari, H. (2016). Peran Kecerdasan Emosional Dalam Pendidikan Karakter. Seminar Nasioanal, 167-174.

Priyanti, L., \& Setyowati, N. (2017). Optimalisasi kecerdasan emosi melalui musik feeling band pada anak usia dini. $E$ Journal.Unipma.Ac.Id, 3(1), 20-33.

Putro, K. (2015). Pengaruh Pola Asuh Dan Interaksi Teman Sebaya Terhadap Kecerdasan Khamim Zarkasih Putro. AlAthfal: Jurnal Pendidikan Anak ISSN, 1(2), 97-108.

Rahmat, P. S. (2009). Penelitian Kualitatif. Journal Equilibrium, pp. 1-8. Retrieved from

yusuf.staff.ub.ac.id/files/2012/11/JurnalPenelitian-Kualitatif.pdf

Ramadhan Lubis, K. (2018). Permainan Tradisional sebagai Pengembangan Kecerdasan Emosi Anak. Al-Athfal: Jurnal Pendidikan Anak, 4(2), 177-186. https://doi.org/http://dx.doi.org./10.14421/alathfal.42-05

Rika Sa'diyah. (2013). Urgensi kecerdasan emosional bagi anak usia dini. Cakrawala Dini: Jurnal Pendidikan Anak Usia Dini, 119.

Yetti, E.-. (2012). Pengaruh Model Pembelajaran dan Kemampuan Gerak Tari Terhadap 
P ISSN 2548-6284 E ISSN 2615-0360

Vol. 4 No. 2 Juni 2020

Kecerdasan Emosional Anak Usia Dini. Panggung, 22(2), 213-224. https://doi.org/10.26742/panggung.v22i2.63

Utama, F. (2018). ESQ Way 165: Alternatif Metode Pengembangan Kecerdasan Emosi dan Spiritual Anak. Journal of Early Childhood Care and Education, 1(1), 7. https://doi.org/10.26555/jecce.v1i1.59 